\title{
The Race of Class: The Role of Racial Identity Production in the Long History of U.S. Working-Class Writing
}

Benjamin Balthaser

This essay would like to pose what may be a provocative question: What if we considered The Autobiography of Malcolm X (I965) as one of the most important U.S. working-class novels of the twentieth century? How might centering Malcolm X's text as part of the working-class literary canon challenge ideas of both working-class literary tradition as well as the political meaning of its genealogy? Critic Michelle Tokarczyk suggests in her recent edited volume Critical Approaches to Working-Class Literature that "working class literature is far broader than the literature produced by politically minded whites" during the "Red Decade" of the I930s (20I I). Certainly, work by critics, such as Alan Wald, Bill V. Mullen, Barbara Foley and many others, have broadened our conception of the racial coordinates of mid-century radical working-class writing, noting not only the contributions of writers of color but the importance of anti-racism to the literary left since the late I920s (Wald, 20I4; Foley, I993; Mullen, I999). And yet, I might take us a step further and suggest that U.S. working class literature has always been about the production of a class identity through modes of racial looking, identification, and solidarity. As Stuart Hall famously wrote, "race...is the modality through which class is 'lived,' the medium through which class relations are experienced," in literature as much as in the practices of daily life (I996). But before I step into an argument about how the boundary-crossing memoir may re-center our idea of a U.S. working class literary tradition, let us consider for a moment how

How to cite this book chapter:

Balthaser, B. 20I7. The Race of Class: The Role of Racial Identity Production in the Long History of U.S. Working-Class Writing. In: Lennon, J. and Nilsson, M. (eds.) Working-Class Literature(s): Historical and International Perspectives. Pp. 3 I-64. Stockholm: Stockholm University Press. DOI: https://doi.org/ Io.I6993/bam.c. License: CC-BY 
the story of the political evolution of black nationalism is also the story of class in America.

The Autobiography is often remembered as one of the ur-texts of the black liberation movement, read alongside Eldridge Cleaver's Soul on Ice (1968) and Amiri Baraka's Dutchman (1964). Many of the scenes stand out as part of the text's collective memory, including a high school English teacher's advice to a precocious young Malcolm to become a carpenter, his legendary conk and his decision to let his hair grow "natural," his conversion to Islam in prison, and his trip to Africa speak to text's primacy of race as determining not only personal, but national and international politics. Yet, I would argue, the pivotal moment in the text occurs not when the young Malcolm converts to Islam, but rather when he rejects his sister Ella's middle-class "Hill” neighborhood for the working class "ghetto" of Roxbury. Up to this point, the young Malcolm has largely been passive, following the counsel of his elders and submitting, reluctantly, to the world as it presented itself to him. Walking literally and figuratively down the Hill and into "That world of grocery stores, walk-up flats, cheap restaurants, pool-rooms, bars, storefront churches, and pawnshops" marks the first intentional, and I would suggest, overtly political act of the text (Haley and X, 20I 5 ).

It is often assumed that the politics of black nationalism obscure or deflect economic differences within the black community (Naison, I983). ${ }^{\mathrm{I}}$ Yet embedded in Malcolm X's "descent" from the middle class Hill into the world of pool halls, musicians, and small time thieves, was the beginning of a novel of distinct class resistance. What attracted the young Malcolm to the life of hipster and hustler had little to do with the politics of assimilation-it was as much a resistance to wage labor, authority, and the carceral state expressed through a racial politics. As he says of his hustling days, "only three things in the world scared me: jail, a job, and the army," or rather, the markers of ruling class power over working class life (ibid.). Shorty's slang for a job, “a slave," ties the hipster's critique of white supremacy to the world of waged work.

This is not to say hustlers and hipsters didn't work. Young Malcolm's first job as a boot-black was valuable not as source of money, but for the connections it provided so he could sell 
"reefer" and engage in other illegal small deals. And most importantly for Malcolm, it allowed him to enter the world of musicians and dance-hall life. Labor was not a value in and of itself, but rather a means to achieve a life of leisure. Wrapped up in this identification is an attack on the work-ethic itself. Malcolm's donning of the zoot suit, as scholars such as Robin D.G. Kelley, Kathy Peiss, and Eduardo Pagan suggest, contained many layers of cultural and representational politics, not the least of which is a rejection of work: rather than emphasize the masculinity of the wearer through broad shoulders and uniformity of style, the suit feminized the wearer through its curves and suggested idiosyncratic excess over discipline and uniformity. ${ }^{2}$ It is a parody of the capitalist uniform.

Indeed, Malcolm X's opposition to the small black bourgeoisie seems less embedded in the cultural affect of assimilation - he continues his life as a hustler long after he abandons the zoot for conservative blue and black suits, noting "a banker might have worn my shoes" (Haley and X, 20I5). Rather, Malcolm X objects to the black middle-class views of capitalism and militarism, expecting to rise just far enough to earn their own share of it. It would be easy to suggest that Malcolm criticizes the black middle class as "trying to imitate white people," and he often lampoons their pretensions to a middle class status that they cannot themselves achieve - janitors at banks describing themselves as "in banking," maids boasting of the distinguished families for which they work. Yet Malcolm also acknowledges that many of the African-Americans on the Hill did own their own houses, have professions, and are "strivers and scramblers," succeeding on their own terms (ibid.). His distaste for the "Hill clowns" cannot only be reduced to a simple delusion that they may achieve whiteness, but rather an entire set of attitudes around class, labor, sexuality, and the state. It's important to note that many of Malcolm X's most militant detractors - from the military nurse who rolls his eyes at him to the black professor he cuts down with "n-word" are members of the black middle class who he opposes on political, rather than cultural grounds. They can hardly be described as people who have achieved nothing in terms of class status or upward mobility. Even Malcolm X's liaison with a married white 
woman, Sofia, is registered as an act of theft, rather than a form of integration or assimilation: "white women...were regarded as stolen property, booty seized in the ultimate hustle," as Robin Kelley observes (1994). In other words, it is not association with white people, per se, that the young hustler objected to, but the relationship of whiteness to class and power.

What obscures the Autobiography's class politics is often the retrospective voice of the narrator, one who emphasizes Malcolm X's rupture with his criminal past as a way to stress the text's narrative of uplift and redemption (Marable, 20I I). Yet as Kelley points out, Malcolm X's later politics as a black nationalist are frequently indistinguishable from his earlier postures as a young hustler, especially as he "lampooned the black bourgeoisie before black working-class audiences" (I994). Malcolm X's most famous (or infamous) critique of the 1963 "March on Washington" is largely expressed through class terms. When $\mathrm{X}$ describes the original idea of the march, it's a portrait of working class and poor radical self-activity, "overalled rural Negroes, small town Negroes, Northern ghetto Negroes...getting to Washington anyway they could - in rickety old cars, on buses, hitchhiking" (Haley and $\mathrm{X}, 20 \mathrm{I}_{5}$ ). And yet, when civil rights leaders took control of the march, this "black powder keg" that planned to "shut down Washington" was transformed not only into a choreographed spectacle, but the class nature of the march changed as well:"It was as if an electrical current shot through the ranks of bourgeois Negroes...any rickety carloads of angry, dusty, sweating smalltown Negroes would have gotten lost among the chartered jet planes, railroad cars, and air-conditioned buses" (ibid.).

Integration for Malcolm X is not about a relationship between white people and black people, but rather the control of one class of already integrated African-Americans over their segregated lessors. Indeed, Malcolm X's claim to leadership lay in his specific ability to communicate and understand the needs of working-class African Americans in contrast to the middle-class black leaders. Approached by a young hustler on the street, the black "'downtown' leader was standing...looking as if he'd just heard Sanskrit” (ibid.). For all of Malcolm X's apparent dismissal of his life as a hustler, he comments after the exchange, "the most 
dangerous black man in America was the hustler," or someone for whom the class power of the black elite holds no sway (ibid.). What emerges from the Autobiography is a subjective class-consciousness articulated through the expression of race. As Eresto Laclau and Chantal Mouffe argue, social antagonisms of class are not static or sociological categories - they are lived, subjective, and political. ${ }^{3}$

What then, to make of Autobiography as a working class text? Typically, discussions of working class U.S. literature run within two parallel trajectories. The first is to assume that by "working-class" we mean the trajectory of literature that begins with the Russian Revolution in I9I7 and responds to the call for a global "proletarian literature," or "proletcult” (see Katerina Clark's essay in this volume). While the formal period of Soviet-sponsored "proletcult" was relatively brief and ended by the late I920s, as Michael Denning notes, the call was answered and by the I930s "a group of landmark proletarian novels emerged," including authors, such as John Dos Passos and Agnes Smedley in the U.S. but also Haiti's Jacques Roumain, Japan's Tokunago Sunao, Peru's Cesar Vallejo, Germany's Willi Bredel, and countless others (2004). Neither a movement in a sociological sense - as many of the authors were not themselves working class - nor reducible to the Party apparatus, one could think of the global proletarian novel as both a political and aesthetic project. In the U.S., the arc of proletarian literature is marked by touchstone essays, such as Mike Gold's "Toward Proletarian Art" (I92 I), Kenneth Burke's address to the I935 Writers Congress, "Toward a Revolutionary Symbolism," Meridel Le Sueur's "Fetish of Being Outside,” (I935), and Richard Wright's "Blueprint for Negro Writing” (I937). These widely divergent essays on proletarian writing in the I920s and I930s have less in common in terms of aesthetic proscriptions (as much as they all differ widely as writers) as they do with an idea that proletarian writing is a kind of working class avant-garde. Denning refers to this movement as the "third wave of modernism," the re-alignment of the global avant-garde with a working-class politics (ibid.; Denning, I998). By this standard, proletarian literature is measured by the articulation of a specific proletarian point of view, the production of a new subjectivity. The task, as Le Sueur 
argues in her manifesto on working class literature, is to "create... the nucleus of a new condition" (I990). It is, as Marshall Berman suggests about all modernist writing, positioned toward the perception of a new, industrialized reality (1982).

The second trajectory locates U.S. working-class literature within a far longer history. David Roediger's The Wages of Whiteness and Eric Shocket's Vanishing Moments: Class and American Literature point to a genealogy of working-class literature that developed over the course of the nineteenth century, in a dialectical engagement with the twin capitalist enterprises of industrial production and plantation slavery. Reading Rebecca Harding Davis' "Life in the Iron Mills" (I 86I), Shocket notes the way in which literary responses to the emergence of an industrial proletariat relied on the racialized imagery of slavery (2000). Davis" text serves to "jar readers with the misapprehension" that the mill workers are "black" with soot, and Schoket argues that Davis understands exploitation by industrial capital as through the language of racialized bondage and chattel slavery (ibid.). For Davis, the site of the wage laborer is not the emergence of a new class so much as the extension of bondage to white men. While this might have served to draw powerful links between white workers and black slaves, such rhetoric more frequently worked to naturalize slavery as a function of racial difference: it is the blackening of white men, and not the condition of exploitation, that becomes the text's locus of dread. Shocket also draws on the extensive antebellum pro-slavery literature critical of wage labor, including George Fitzhugh and Williame Gilmore Simms, who argue that industrial labor degrades the worker and produces an "inferior race of men" (ibid.). As David Roediger points out, languages of race and class emerge at the same time and are co-constitutive (I996). Race became the language through which forms of labor exploitation came to be witnessed, exposed, and understood.

This emergence of class through the articulatory process of race has another more interesting implication: We might begin to think of slave narratives as the first working-class fiction in the U.S. As C.L.R. James and W.E.B. Du Bois have argued, one cannot appreciate the importance of slavery to the global economy, or the role of black resistance to slavery, without understanding 
that black slaves were the mid-Atlantic's first proletariat (James, I989; Du Bois, I998). Uprooted from their origins, clan, and previous caste, slavery threw millions of people into a proto-industrial economy that mobilized advanced forms of credit, technics of labor discipline, and the new mobility of shipping to create an army of bonded labor. ${ }^{4}$ Du Bois's description of the first "general strike" in the history of the U.S. to describe slaves walking off their plantations to Union Army lines emphasizes not only the agency of black labor but their understanding of themselves as a class. If seen this way, we can begin to think of slave narratives as a kind of working-class literature. Frederick Douglass's I 845 memoir The Narrative of the Life of Frederick Douglass, an American Slave details not only his efforts to free himself from bondage but to gain control over his body and thus his labor. His strugglefirst over Covey and then to retain wages earned as a caulkerare inseparable from his plans to escape North. While Douglass' description of Boston Harbor at dawn can be read as utopian fiction-industrious shipyards, bustling masons and clerks, coppery light and clean salty air-it is nonetheless a tribute to the dignity of labor. Harriet Jacob's Incidents in the Life of a Slave Girl (I86I) is equally a narrative about control over the narrator's labor, or in this particular case, her reproductive labor. Douglass retains mastery over his own body, while Jacobs retains control over her children - a radical act of self-possession, especially as establishing conventional gender roles for former slaves would be understood as an act of proving one's humanity.

It must be noted however, that most if not nearly all workingclass literature from the I 9 th century was literature about working class people, seldom by them and even more rarely, from their perspective. Davis' Life in the Iron Mills is instructive here: The narrator is an omniscient middle class observer who leads the reader from a well- established home and into the lives of mill workers. In this sense, the novella is as much about the workers as it is about middle-class apprehensions about workers - their morality, their liminal racial status, and above all, their real and symbolic proximity to the narrator's home. Like Jacob Riis's 'Lantern Shows' of the urban working classes, I9th century literature about class was often an attempt to provide a kind of surveillance over the poor. 
Benevolent at times, and reactionary at others, its function was to act as a layer of mediation between the poor and the ruling elite. This form of mediation is, in many ways, also the logic of the slave narrative. While Douglass's first-person memoir powerfully constructs his own self-possession, it is also a mediated text, verified by well-known white abolitionists who must testify to Douglass's character, especially his honesty, industry, and his "meekness" This seems a surprising claim for a man who wins his freedom, at least in part, by physically defeating a stronger and older, white overseer (Garrison, I995). As Amy Kaplan articulates in The Social Construction of American Realism, the realist novel is constructed as a kind of literary Central Park, a well-mannered site at which all classes can converge and, it is hoped, form a lawful democratic polity (Kaplan, I988). William Dean Howells novel, A Hazard of New Fortunes (I890), constructs this vision as a dinner party, at which an upper-middle class writer hosts a dinner for the owner of his magazine, as well as the working-class immigrant translator. One gets the sense that for Howells, had the dinner been successful, democracy might have been achieved.

The twin trajectories of working class literature - as an avantgarde movement of politically working-class writers and as a literature marked by racial modes of seeing and identification - came together in the I930s, as an increasingly influential Communist Party and other left organizations placed race/ism at the center of anti-capitalist strategy and analysis. In the words of Hakim Adi, the Communist Party became the "era's sole international white-led movement ... formally dedicated to a revolutionary transformation of the global political and racial order" (2009). In the U.S., anti-racist Communist Party-USA (CPUSA) activity included expelling "white chauvinist" members after public trial, integrating labor unions and Party social events, recruiting African-American members, and most famously, defending the Scottsboro Boys from the death penalty (Naison, I990). As scholars, such as Robin Kelley, Barbara Foley, James Smethurst, Alan Wald, and Bill Mullen noted, the Communist Party also became a major site for African-American cultural production. ${ }^{5}$ While few African-American writers publically announced their membership as did Richard Wright and later W.E.B. Du Bois, nearly all 
African-American writers in the I930s were either members of the party or at least "fellow travelers," including Claude McKay, William Attaway, Frank Marshall Davis, Lorraine Hansberry, Audre Lorde, Ralph Ellison, Chester Himes, Sterling Brown, Langston Hughes, Paul Robeson, Countee Cullen, Alain Locke, Ossie Davis, Dorothy West, Robert Hayden, and many others (Wald, 2000). ${ }^{6}$ The cultural impact of both Communist Party policy as well as the sheer number of African American intellectuals attracted to the Party at this time had a profound impact on U.S. political and literary culture, wedding anti-racism and the African-American freedom struggles to the left in ways that are still actively felt.

This is not to suggest the Communist Party invented the U.S. obsession with ways in which class and race are co-constituted; rather, one could say, it turned the abject fear of "racialized" waged-workers into a point of solidarity and revolutionary potential. As I will discuss below, recognizing or identifying one's racialized status as a worker or with other workers became a marker of political awareness. As Michael Denning reframes Stuart Halls's famous phrase, "ethnicity and race had become the modality through which working class peoples experienced their lives and mapped their communities" (I998). Clearly, The Autobiography of Malcolm X fits neatly within the trajectory of I 9 th century working class literature. The text pays tribute to Douglass's Narrative, from its opening with an act of racist violence, to the natal alienation he faces with the loss of his parents, from the struggle for self-possession and uplift through a growing political awakening, to the quest for literacy. And one could also say it is a text that ironically signifies on Douglass's Narrative, opening where Douglass closes - in the North. No longer a producer's republic of small craftsmen in Douglass's vision of Boston Harbor, the North is produced through racial and economic division, a division enforced in equal parts through deception and violence. The Autobiography returns back to the igth century, when class was understood as a category produced in relation to a racialized institution of slavery. And yet one can also think of the Autobiography as an extended meditation on the class lines within the African American community, and how a politics of 
black liberation must recognize class as having its own discursive and material logic. Indeed, after his hajj to Mecca, Malcolm X articulates what racial theorists Michael Omi and Howard Winant would call a Gramscian theory of race: Whiteness is not a blood quantum or phenotype, but rather as Malcolm X says, "attitudes and actions toward the black man." In other words, it is a political project, one with a distinct class character (Haley and X, 20I5). Rather than think of Malcolm X's politics of black nationalism as a rupture with the earlier 20 th century proletarian movement, I would argue it is a fulfillment of it.

\section{Proletarian Literature: The Epistemology of the Working Class}

Neither Malcolm X nor the much more conservative Alex Haley identified themselves with the proletarian literary movement in the U.S.; nonetheless, The Autobiography bears as much in common with theoretical aims of proletcult as it does with the long history of writing on class and race. The Autobiography is more than just a political tract - it powerfully argues for the subjectivity of working-class African Americans. The problem with integration for Malcolm $\mathrm{X}$ is as much a question of racial purity as it is the middle-class nature of integrationist organizations; the working-class hustler is under no such illusion. And yet, workingclass literature is thought to be less a concern of working-class subjectivity and an inheritor of the particular class struggles of a given nation, but as a formal question of realism. Often when discussing the theoretical origins of proletarian literature, the genre of "social realism" is forwarded as a short-hand for the entire movement. Georg Lukacs' The Historical Novel (1937), with its examples rooted in nineteenth century authors and its call for a dialectic between surface transparency and social complexity, is understood to have articulated the intellectual framework of the genre. Yet as James Murphy states, even at the moment of proletcult's articulation during the Bolshevik Revolution, such a point of view was only one among many (I99I). What is clear from his accounts of Party intellectual debates, proletcult was to give voice to worker-writers and display class struggle - yet questions of genre 
and style were left relatively open. As Michael Denning argues in The Cultural Front (1999), the proletarian literary movement should be considered an experimental avant-garde, stylistically innovative and self-reflexive (I998). ${ }^{7}$ Indeed, I would suggest what unites post-Revolutionary working class literature is not a style but rather a particular epistemology toward the meaning of class.

It is not the Soviet literary critic of Lukacs' Historical Novel, but rather the I920s avant-garde theoretician of Lukacs' History and Class Consciousness that should be seen as the intellectual framework for self-consciously working-class literature in the 2oth century. As Frederic Jameson writes, Lukacs' History and Class Consciousness (1923) forcefully argues that the working class is defined by more than just a political project, rather the text is a "prophetic invocation of a radically different class logicthe praxis as well as the new epistemological capacities of the industrial working class" (2009). For Lukacs, the working class is confronted by twin crises: both its exploitation by another class, but also its reification, or the abstraction of both its life and its labor from a totality of being and into a thing-a commodity. The irony for Lukacs is that the very status of "worker" is a negative category, as it implies both the fragmentation and compulsion of their labor and self. The task of a proletarian political movement is to be aware of one's objectification within the processes of production and consumption. Indeed, for the bourgeoisie, their life and interests are identical with their objective position with the capitalist mode of production. For the working class, they must develop a point of view that is not only objective, but subjective as well. Quoting Hegel, Lukacs articulates such working-class subjectivity as the moment in which a class becomes "conscious of its own essence" and that it "possesses its absolute truth only in this recognition and not immediately in its existence" (I972). In other words, the consciousness of the proletariat exists not only in an accurate, factual representation of its own condition, but in a collective awareness of a future in which its labor and life are free from contradiction. Putting it more simply, Lukacs states that the only way to "break through this barrier" of reification "is to overcome it inwardly from the very start and develop its own point of view" (ibid.). 
It would be incorrect to conflate realism with proletarian literature by this definition. Realism, to use William Dean Howells' formulation, desired to depict the "phrase and carriage of everyday life," an accurate depiction of reality based on the empirical facts of human observation. Harding Davis' Life in the Iron Mills, as with Howells' Hazard of New Fortunes, relies on an often 'neutral' observer, recording the world around them and offering mediation between the opposing class forces. For Lukacs, this kind of realism recalls the "static" world of bourgeois history, in which the "untranslated immediacy of facts" conceals not only the ongoing transformation of the "objective forms of life" through class struggle, but the reification of reality: the commodification of social relations appears as normal or naturalized (ibid.). Furthermore, for Lukacs, this form of narrative representation is the hallmark of bourgeois art, even when deployed for radical ends. Referring to such realism as "reflection theory," such art freezes reified social relations into place (ibid.). "Reality is by no means identical with empirical existence," Lukacs argues, suggesting that reality is a "complex of processes" that are always in motion, a "process of Becoming" (ibid.). Thus, the working class is both subject and object, or what Lukacs refers to as the "subject-object of history"both captured within reified social relations, but also due to its particular standpoint, capable of overcoming and transforming its reified reality through a revolutionary movement.

One could say that for Lukacs, proletarian art is in tension with the reality it seeks to document-at once in need of exposing the class relations of production, while also critically undermining the very reality that produces such relations. It is a dialectical vision of art and reality, produced by the processes it seeks to undo. Frederic Jameson refers to Lukacs' theory of subjectivity as a prefiguration of "standpoint theory," which poses that one's reality is produced through membership in a particular social group (2009). And yet, unlike standpoint theory, identity for Lukacs is materially constructed, but never fixed. It is produced in a constant process of ongoing class relations and social forces. One can think of a standpoint emerging on a social terrain constantly in motion - materially fixed in one sense, but uneven, in process, and fluid in another. Often one can perceive this tension 
revealed in proletarian novels by their uneasy relationship with their own temporal range - contra the bourgeois novel, the span of one person's life. In Myra Pages's The Gathering Storm (I934), the novel refuses to concede the defeated textile strike as a finality and, rather, looks to a mobile and dynamic image of a storm on the horizon, yet to be realized. Likewise, the final pages of Mike Gold's Jews without Money (I930) points to a revolutionary future that will redeem the suffering of a "lonely, suicidal boy" (Gold, 2009). One can think of the temporal tensions between Malcolm X's hustler past and revolutionary present as caught between objects and subjects of history.

\section{Blueprint for (Working-Class) Negro Writing: A Question of Perspective}

One essay, in particular, brings together the two tendencies of proletarian literature in the twentieth century - both the intersecting legacy of race and class in radical writing, as well as the dialectical tension of the "subject-object" of history. Richard Wright's essay, "Blueprint for Negro Writing” (I937), is a call for AfricanAmerican writers to directly address the needs and concerns of working-class African Americans, while also bringing to bear a social analysis that ties together daily struggle with the workings of global capitalism. Wright signifies on W.E.B. Du Bois's formulation that the "talented tenth" of educated African-American men should be the political and moral leadership of the AfricanAmerican community, pointing out that the African-American working classes are politically far ahead of the educated AfricanAmerican intelligentsia:

Lacking the handicaps of false ambition and property, [workingclass African Americans] have access to a wide social vision and a deep social consciousness. They display a greater freedom and initiative in pushing their claims upon civilization than even the petty bourgeoisie. Their organizations show greater strength, adaptability, and efficiency than any other group in society. (Wright, 2007)

Like Lukacs' own theory of working class agency, the AfricanAmerican working classes are materially positioned to resist 
identification with the ruling class; indeed, they are positioned to resist reification. Much like Malcolm X's critique of the black middle class, Wright condemns literary production of the "rising Negro bourgeoisie" as "decorous," couched in "servility" and emblematic of an entire class- "bloodless, petulant, mannered, and neurotic" (ibid.). He suggests that black middle-class writers are alienated even from their own works, that "at best, Negro writing has been external to the lives of educated Negroes themselves." Like Malcolm X's critique of the "Hill clowns," they are performing the alienation of a reified, capitalist society to which they wish to belong.

And yet, Wright believes there is a necessary role for literary production. Much like Lukacs' observation that to perceive one's "objective" status within a mode of production is necessary but not sufficient to produce a revolutionary consciousness, Wright also argues that working-class African-American "folklore" blues songs, oral tradition, jazz - articulates "the collective sense of the Negroes' life in America" and marks the "vital beginnings of that recognition of value in life as it is lived." Yet Wright also acknowledges that African-American folklore by itself is not sufficient to lead a transformation of African-American political culture. He describes it as "nationalist" in orientation, and perhaps more than anything else, it lacks a global analysis of how the black liberation struggle fits within capitalism and colonialism. The nationalism of African-American folklore needs to be learned, respected, and understood; yet it is the role of the educated (or in Wright's case, self-educated) writer to re-construct a systemic analysis - what Lukacs would call "the social totality." This "aspiration to totality," which marks un-reified class consciousness for Lukacs, is a global understanding, to demonstrate how immediate events are complex, interconnected, and part of a larger system logic (Lukacs, I972).

Wright refers as "a question of perspective" this understanding he feels is the special task of the African- American writer. I believe this is what Lukacs would refer to as "subjectivity." The relationship between the writer for Wright and revolutionary consciousness mirror one another. For Wright, it is the writer who must demonstrate the most advanced consciousness of the working class: 
It means that Negro writers must learn to view the life of a Negro living in New York's Harlem or Chicago's South Side with the consciousness that one sixth of the earth's surface belongs to the working class. It means that Negro writers must create in their readers' minds a relationship between a Negro woman hoeing cotton in the South and the men who loll in swivel chairs in Wall Street and take the fruits of her toil. (Wright, 2007)

Meridel Le Sueur articulates a similar principle in her I 935 essay, "The Fetish of Being Outside," contending that it is the writer's "peculiar and prophetic function to stand for a belief in something that scarcely exists...the nucleus of a new condition and relationship to the individual and society" (I990). For Le Sueur (as for Lukacs), the role of the writer is both objective and subjective. Lukacs's tension between the documentary and revolutionary character of class consciousness is to be resolved by the revolutionary writer. She acknowledges that the "dark, chaotic, and passionate world of the proletariat" is not necessarily revolutionary, and yet articulates the role of "belief" as the writers' function to not just document but to also articulate an unreified social existence that does not yet exist. Yet for Wright, Le Sueur's metaphor of the "dark...passionate" world of the proletariat has very literal connotations: the black writer for Wright not only represents the working class, but the global non-white world.

\section{The Race of Class: The Proletarian Novel as Ethnic Bildungsroman}

It would be impossible to talk about the development of workingclass writing in the United States without a discussion of Mike Gold and his autobiographical novel, Jews without Money. Often taken to be the ur-proletarian novel of "Red Decade" of the I930s, it was seen then and in retrospect as "a road marker to guide the proletarian literature that followed" (Rabinowitz, I99I). In part, this owed to Gold's already outsized role as editor of The Liberator and then The New Masses, both avant-garde intellectual publications of the CPUSA. As editor, Gold wrote columns and manifestos calling for and defining what proletarian literature in the U.S. should be. Much like Richard Wright and Meridel Le 
Sueur's literary manifesto written over a decade later, Gold placed the subjectivity of the working-class writers at the center of his I92 I "Toward Proletarian Art." Writing that proletarian literature needs to be drawn "from the depths upward," Gold describes "Art" as the "tenement pouring out its soul through us" (I972). As a construction, the writer becomes a conduit not only for their personal experience but also for the entire social structure of capitalist inequity. Indeed, the writer's subjectivity is identical with his/her own positionality within a capitalist framework. The image of the depths moving toward the surface also calls to mind a deep materialism, in which the writer's psychological "depths" merge with the "base" of the literary superstructure. Much like the working-class literature of the proletarian movement that Lukacs theorized, Gold's essay calls for an objective-subjectivity.

Yet for the ur-text of proletarian literature, Gold's novel raises important questions about what the term means. Even though Gold calls his I92 I manifesto a work of literature about the "strike, boycott, mass-meeting, imprisonment, sacrifice, agitation, martyrdom, organization," Jews without Money is nearly free of any mention of revolutionary organizing until the final two-page invocation. As Michael Denning writes in The Cultural Front, the novel is a "ghetto pastoral," and the impact the novel had on American literature is less its call for revolution, but rather its placement of the urban, ethnic, immigrant landscape at the heart of the working-class imaginary. Often far too much attention is paid to the novel's call for revolution in its final pages. The content (what Denning refers to as its "form") is the "tenement pastoral," a genre "that Gold helped invent" and which went on to "became one of the central forms of proletarian fiction" (Denning, I998). In other words, while Gold himself may refer to the Bolshevik revolution as his inspiration and Walt Whitman as his national icon, to locate the primal scene of proletarian literature in an immigrant ghetto is less a break with the past as a fulfillment of its contradictory impulses. It should thus come as little surprise that Gold's novel created such a sensation in revolutionary literary circles: It provided a model not so much for revolutionary agitprop, as it did to combine the call for proletarian writing with the racial matrix of class in the U.S. Furthermore, the book not only located 
race, language, national status, and ethnicity at the heart of the experience of class, but it also provided a ground for the narrator to locate his own racial and classed identity within a racially bound urban center.

As a novel about revolution, Jews without Money is fairly straightforward: Its young narrator observes through the multiple failures and defeats of his parents and comrades that there is no way out of his poverty but through collective, revolutionary action. And indeed, the novel is often derided as a "conversion" narrative, perhaps one of the easiest and least interesting modes by which a proletarian writer may overcome the Lukacian tension between proletarian literature's objective and subjective character. Yet as a novel about race, Jews without Money is profoundly complex in its treatment of the Jewish inhabitants of the New York City East Side ghetto. They are at once distinct as Jews, as immigrants and non-citizens, as non-whites, and equally as importantly, as nonblacks for whom full citizenship may at some future time hold promise. Indeed, the Soviet cultural formula, "national in form, proletarian in content," may refer not only to the novel's status as ethnic literature, but rather that the U.S. is a place in which class gets made through race. Thus, the decision the narrator has to make, in one sense, is what race he may decide himself to be. It is not a new question within Jewish literature - as Abraham Cahan's hapless narrator in Yekl (I896) abandons his dark, Orthodox "squaw" of a wife for the translucently white, secular Mamie, or more (in)famously, Jackie Rabinowitz becomes "Jack Robin" just long enough to leave the ghetto for uptown blackface performance in the 1927 film The Jazz Singer.

It should also be noted that the politics of immigration took a dramatic turn to the right during the years of Gold's radicalization in the I920s. Responding in part to the rise of the 2 oth century $\mathrm{Ku}$ Klux Klan, the I924 passage of the Johnson-Reed act enacted "national origin" quotas that were intended to reduce immigration from Southern and Eastern Europe to almost zero. The rise of the anti-immigrant and anti-Catholic/anti-Jewish Klan hardened racial lines in the I920s, shifting national discourse from "melting pot" assimilation to an ideology of biological racial difference and often equating African-Americans and Southern/Eastern Europeans as 
not only culturally inferior (and in need of "Americanization"), but genetically inferior (Daniels, I998). Jews, in particular, were singled out as "abnormally twisted" and "unassimilable," linking them phenotypically with African Americans and Asians (ibid.; Jacobson, I999). The I924 Act also divided the globe into East and West, marking all of Asia as one single racial category, while differentiating European immigrants by geographical proximity to Asia and Africa (Ngai, 2004). Gold's novel responds to the new racial matrix of non-Western European immigration by substituting a teleology of assimilation for a teleology of revolution. And yet Gold's teleology of revolution - based on Jewish-black identification does not rely on a universal, unmarked subject. Rather, it is through Gold's identification with a racial marked Jewishness that he comes to his political awakening.

Jews without Money is the first prominent Jewish novel published in the U.S. to not only resist assimilation entirely, but to also embrace Jews' liminal racial status as a positive class marker of resistance. As William Maxwell points out, Gold came to the "conclusion that it was self-destructive for Jews to adopt the course of other European immigrant groups and inch toward the status of full-fledged white Americans by learning to loathe blackness" (1996). Maxwell continues by arguing the black haired, swarthy, broad-nosed, impoverished Jewish adolescent described as a "gypsy" and nicknamed "Nigger" by the community transgresses the boundaries of race at a moment in which racial difference was assumed to be biologically rooted (ibid.). In an historical moment in which racial categories were understood to be "self-evident" and "immutable," "Nigger" both undermines racial binaries but also locates race as a political relationship to power. In other words, it identifies with African Americans at a moment in which Jews were internally and externally pressured to assimilate.

"Nigger" was far from an outcast for Gold. Indeed, Mikey, the narrator, regarded him as one of the heroes of the text. "He was ready to die for justice," Mikey says of his adolescent friend after he resists a police officer's order to disperse from an illegal dice game. Mikey notes that the cops routinely harassed the children in the neighborhood, stealing money, sports gear, and violently treating the kids like "criminals" (Gold, 2009). Expected 
to forfeit the pennies to the cop after fleeing, "Nigger" leads the cop on a foot chase, finally leaping between buildings to avoid being caught. Continuing the criminalization of ghetto youth, Gold refers to the school as a "jail" and proudly boasts that "Nigger" hit a teacher "on the nose" after the teacher called Mikey a "little Kike" (ibid.). "Nigger" defied the racist and anti-Semitic authority against which Mikey and his friends fought, both on the street against rival Irish and Italian "Christian" gangs, as well as the official authority of the state manifested in the school system and the police.

While Baruch Goldfarb, a wealthy Jew, is described as a "Zionist leader," it is "Nigger" and the novel's other racially liminal gangster, "Louis One-Eye," who form "the valiant armies... in defense of the Jews" of Mikey's dreams (ibid.). It is "Nigger" who not only defends the young Mikey from his anti-Semitic teacher but also leads the gang against the other ethnic gangs of Irish and Italian youth in the Lower East Side. Equally, Louis One-Eye, while a predatory gangster and one of the villains of the book for entrapping Mikey's aunt into prostitution, defended the Jewish community against a mob of anti-Semitic Italian youths who assaulted elderly Jewish men (ibid). It should be noted that One-Eye (like "Nigger") received his education about the American state through the prison system, where One-Eye both lost his eye to police torture and also earned his reputation for fierceness.

Curiously, Mikey refers to "Nigger" as both someone who "scalped Indians" and "shot the most buffalo among the tenements," while also describing him (and the gang of which Gold was a part) as Indians, with "Nigger," the "chieftain of our brave savage tribe" (ibid.). As Richard Slotkin notes, the terrain around metaphors of the West underwent a profound shift in the I930s, with the Western entering into a period of eclipse in the early I930s, as urban crime dramas and gangster films portrayed a gritty world of poverty, criminality and desperation (Slotkin, I998). As the city became a site of both crisis and political conflict in the deepening Depression, the ethnic gangster became a kind of "urban savage," tamed by the lawman of the city instead of the Indian-fighter of the frontier. Signifying on this trope, Gold both articulates "Nigger" as simultaneously the Indian-fighter and the "Indian" at the same 
time, with Gold's gang figuring as both his "braves" and his deputies. Gold never resolves this contradiction in the novel, even as fantasies of both the Western, as well as "the charge up San Juan Hill" by Teddy Roosevelt, figure frequently in the text as marks of the narrator's "Americanized" imaginary. Rather than suggest their lack of resolution poses a problem, I would say these seemingly opposed and even contradictory images - in which Gold's gang is both "Indian" and "Indian-fighter" - speak to the contradictory racial logic of the text. Mikey acknowledges not only his character's whiteness in relation to African Americans in the text - especially as his mother befriends black workers in the kitchen in which she works - but also the liminal and othered racial status of the Jew. Rather than see race as a fixed category, Gold mobilizes it as one of political and class solidarity. "Nigger" is not "black" because of his dark skin. Rather, his "blackness" emerges from his oppositional stance and his defense of what Gold refers to as the "the Jewish race". As perhaps the greatest irony for the "chieftain of a savage tribe," "Nigger's" father hangs a poster of the Roosevelt's charge up San Juan Hill in his living room, even as it is the very army exterminating "the savage" abroad in U.S. colonial wars Gold spent years opposing (Gold, 2009).

It should also be noted that such liminal racial identifications are not in effect with members of the Jewish elite. Zechariah Cohen, Mikey's father's boss, wants Mikey's father to buy real estate in what were then Brooklyn suburbs. Cohen's wife, "glittered like an ice-cream parlor" with her bleached hair and talked only of how much money she can spend, the rich foods she eats, and her expensive taste in clothing (ibid.). The suburb itself, for "refined Jewish businessmen," is a site of emptiness and isolation, where "paved streets ran in rows between empty fields" and in a "muddy pool where ducks paddled... a sign read 'Build Your House in God's Country'" (ibid.). Gold represents the suburbs through the figure of Mrs. Cohen, as a space of whiteness and consumerism. They represent a rise in class status and a removal from possible racial associations with non-whites. To represent the suburbs as a site of emptiness and isolation suggests that whiteness and economic success - "my fine expensive furniture, my hand painted oil-paintings, my up-to-date water closet" - is 
literally and figuratively a dead end, a site of empty houses and desolate lots (ibid.).

While the Jewish messiah who Mikey waits for is secularized into a call for "workers' Revolution" in the final page of the novel, what is clear in the text is that Mikey's path lay not with the frontier figures of his imagination nor the white suburbs of his father's dreams. Instead, Mikey joins "Nigger's crowd," which leads him, just a paragraph later, to wander into the fateful aura of the East Side soap-box oratory introducing him to his new life purpose (ibid.). While "Nigger" himself is not a revolutionary, the novel's arc only makes sense as a series of identifications in which the narrator learns less about his politics than about his identity. In other words, Mikey's politics are his identity. As a narrative, Jews without Money seems to have no plot. It is a series of anecdotes about Mikey's childhood on the Lower East Side. Yet, as a fictional narrative, the novel's tension lay in the narrator's decision to join with the "dark proletarian instinct" of his mother, rather than the dreams of whiteness imagined by his father (ibid.). The "darkness" of his proletarian instinct seems to have a distinct racial cast, as the phrase perhaps unwittingly suggests. If the tension in proletarian identity for Lukacs lay in the contradiction between the lived reified present and the social totality, the tension in Jews without Money is not resolved by the call to revolution. It is resolved through the narrator's decision to align himself racially with members of his own class, rather than abandon them for a dream of success or a flight of middle-class fancy.

Given the seminal nature of Jews without Money in defining U.S. working-class literature after the I930s, it is interesting to note the direction that proletarian literature did not take in the decades following. At near the same time of Jews without Money's publication, a slew of novels exploded into the American literary scene, fictionalizing the Gastonia, North Carolina textile strike. These included novels by well-known writers and journalists, such as Sherwood Anderson's Beyond Desire (1932) and Mary Heaton Vorse's Strike! ( I930), as well as intellectuals closer to the Communist Party orbit, such Grace Lumpkin's To Make my Bread (1932), Fielding Burke's Call Home the Heart (1932) and Myra Page's Gathering Storm (I932). Despite their coverage of political 
events and their far more open and direct treatment of collective labor organizing, the novels quickly faded from view (Denning, I996). They received ample press attention, as did the strike they recorded. Two novels, To Make my Bread and Gathering Storm, even received prior publication in the Soviet Union and official state backing (Foley, I993). Yet, as Denning notes, the authors were all "outsiders" and largely journalists, equated more with topical writing than with the proletarian tradition (Denning, I996). That is to say, they lacked the quality of subjectivity and the production of identity that novels such as Gold's made central to their narrative arc.

These set-piece proletarian novels ended up as more of a footnote to literary history, rather than the beginning of a new literary movement - much as the actual Loray Mill strike at Gastonia failed to ignite a new interracial workers' movement, despite the heroism of the strikers and organizers. Many of the touchstone working class texts of the I930s and I940s, including James Farrell's The Studs Lonigan Trilogy (I935), Clifford Odets' Awake and Sing (1935), Philip Roth's Call it Sleep (I934), Nelsen Algren's Never Come Morning (1942), Chester Himes' If He Hollers (1945), Ann Petry's The Street (1946), Richard Wright's Native Son (1940), and Carlos Bulosan's America is in the Heart (1943), are more an exploration of the ethnic and/or racial self through the classed structure of power than they are truly novels of organized, working-class revolt. In this sense, Pietro Di Donato's I939 Christ in Concrete is instructive. The novel opens with Geremio, a master brick layer in charge of his Italian-American crew, labeled as "wops" and "Dagos," justifying both the foreman and the building contractor to ignore the very safety violations that condemn Geremio to his "crucifixion" as the building collapses upon him (di Donato, I993). A "wop," to the building contractor, is the status of a non-person, or a body to which full consideration need to be give, either during life, or after death. Geremio's wife learns this when she attempts to collect his death benefit - a benefit not awarded to non-citizens. Geremio refers to himself and friends as "Christians," denoting both their inherent value and equality before God, but also his submission to his foreman, or what the novel refers to as "Job." Both his dehumanization and submission before 
work are redeemed when his son, Paul, refuses both the cross and submission to his boss, telling his mother that he demands "justice" (ibid.). Yet what characterizes the novel is not so much the schema of the son's awakening, as the strange and often stilted language of the omniscient narrator, who details Italian-American life in an English that feels almost as though it is a translation. This strangeness, or duality within the language of the novel, is as much the "content" as Paul's final act of rebellion. They are inseparable from one another. Paul's first act of aggressive speech is also rendered against this mother's Italian-inflected phrasing, suggesting that their conflict is as much a question of identity as it is one of politics - or that the two are one and the same.

I would go so far as to suggest that, at least, part of the effective power of John Steinbeck's Grapes of Wrath (1939) - by far the most popular working class novel of the 2oth century lay precisely in the racialization of Tom Joad's body from white, protestant male to "Okie," signifying through the perception of difference the Joad's loss of class and racial status. The Joads understand themselves at the outset of the novel as not just farmers but as members of a pure racial stock. As Roxanne Dunbar-Ortiz points out, Steinbeck, as a result of his own racist views, got the racial self-image of the "Okie" migrants right: Many of the Okies were descendants of the original Scotch-Irish settlers and viewed themselves as Jacksonian Democrats, defenders of raciallydefined, white, egalitarian virtue (2002). Their awareness of their new racial status is revealed slowly throughout the novel, charting Tom Joad's own subjective transformation from criminal to revolutionary. Bathing naked in a river, the Joads hear the word for the first time, spoken by another migrant who is returning back to Oklahoma from California. Asking what "Okie" means, the other bather replies, “Okie....means you're a dirty son-of-a-bitch. Okie means you're scum” (Steinbeck, 2006). The invocation of "dirt" and "scum" - particularly as the Joads are in the process of bathing - suggests a coloration of their bodies, a metaphoric darkening. Already poor, the Joads not only lose their land and must sell their labor to survive, but their bodies become targets of both the state as well as exploitation by large growers. The Joads become proletarianized in the novel, or another way to say it, they 
experience class through a process of racialization, of othering through a signification on the body. The tension of the novel is precisely between the objective nature of the Joad's class status and the subjective experience of losing their previous status as white people.

Up to this point, I've primary deployed examples of I930s working class literature as written by white and/or white-ethnic authors. This has been deliberate, as I've hope to demonstrate how race and identity became the primary trope through which class identification was expressed, even for writers not typically thought of as "race writers." Of course, however, much this was true for white/ethnic writers, African-, Native, Asian- American and Latino/a writers of this period developed a complex and subjective vocabulary around racial identity similar to, but far more nuanced, than the white-ethnic writers I've mentioned thus far. Many of the seminal novels by writers of the color in the I930s open with or feature a moment of racial dis-identification, in which the narrator's/character's own subjective sense of themselves is confronted by an understanding of the way they are interpellated within a system of racial dominance. One can think of Richard Wright's Native Son, in which Bigger expresses his understanding of race as both material and subjective: the plane he is not allowed to fly and his anxiety located at the center of his body. Or Ann Petry's Lutie Johnson of The Street, who reflects on her own domesticity while seeing an advertisement for a kitchen owned by white people. Or Carlos Bulosan's America is in the Heart that opens with the alienation of Allos watching what appears to be a stranger, but later revealed as his own brother, returning from the war he fought for the U.S. colonial power in Europe.

What connects these moments in the text is a Lukacian concept of subjectivity, one of that is both material and identitarian at the same time. Perhaps the most far-reaching and complex articulation of a subjective and objective view of racial history is Wright's I 2 Million Black Voices (I94I), the second-person, non-fiction photo-essay, in which Wright narrates the Great Migration from the rural South to the urban core of Chicago. Wright uses the Great Migration as a means to explore his own sense of AfricanAmerican subjectivity, in which he locates the double-consciousness 
of African Americans as a consequence of living both within a feudal and modern capitalist economy at the same time.

Standing now at the apex of the twentieth century, we look back over the road we have traveling and compare it with the road over which the white folk have traveled, and we see that three hundred years in the history of our lives are equivalent to two thousand years in the history of the lives of whites! .... Hurled from our native African homes into the very center of the most complex and highly industrialized civilization the world has ever known, we stand with a consciousness and memory such as few people possess. (Wright, I94I)

Taking a page from section 8 of Marx's Capital, Wright addresses the unique context of the African American entrance into capitalist modernity. At once part of the primitive accumulation of capital and at the center of the capitalist metropole, African Americans are situated as no other group in the United States. They exist at both the most brutal, underdeveloped and the most advanced sections of capitalism simultaneously. For Wright, this not only gives a material shape to African-American thought, he offers this historical simultaneity as the particular subjective insight African Americans have into the West.

\section{Class in an Age of Fragmentation: Wither the Present?}

Returning to The Autobiography of Malcolm X, I hope it should be clear at this point how it is not a rupture so much as a fulfillment of twentieth century traditions of self-conscious working-class writing. The development of both the racial and class consciousness and identity of the narrator, its insistence on a unique and subjective expression of a racialized class politics, and the generic form of the bildungsroman all mark it within the tradition laid out by Mike Gold, Richard Wright, Carlos Bulosan, Pietro Di Donato, James Farrell, Ann Petry, and countless others. It should also come as no surprise that Malcolm X himself developed theories of anti-capitalist and socialist politics after his break with the Nation of Islam. Malcolm X regularly spoke at labor union rallies and shared the stage with revolutionary socialists in the last year of his life. As George Breitman 
points out, Malcolm X became increasingly critical not only of capitalism, but of theories and actions around racial liberation that did not also address class exploitation as well (Breitman, I970). And I would suggest reading The Autobiography as not so much a change of direction for Malcolm X than a further articulation of the politics he already expressed throughout his life. The stylistic contours of his autobiography position Malcolm X within the longer trajectory of both working-class politics as well as working-class literary production. Similarly, in the revolutionary upsurge of the I960s and early I970s, we can think of Ernesto Galarza's I97 I Barrio Boy, and John Rechy's I963 City of Night as part of the same literary inheritance.

In terms of contemporary working-class literature, it seems little surprise that Latino/a writers most self-consciously adhere to the tradition laid out by an earlier generation of proletarian artists. In one sense, working-class literature has often been the literature of immigrants. As Mike Gold writes, America's wealth is the product of "the tragedy of millions of immigrants," as migrants both then and now often form a super-exploited class of workers (2009). ${ }^{8}$ And as Michael Denning points out, much of the revolutionary culture of the I930s was the product of the children of immigrants (I998). I would also argue that immigration itself is a process of racialization through class. As Mae Ngai and Lisa Lowe note, the racial status of migrant workers is managed and reinforced by their place on a labor hierarchy in the U.S. (Ngai, 2004; Lowe, I996). But more than sociology, many migrants themselves hail from countries in which the Left, and its traditions of working class representation, are still part of public and popular discourse. Processes of suburbanization, whiteness, and the unhealed scars of the Cold War's multiple red scares have erased much of the memory of working-class literary production in the U.S. For complex historical reasons, Latin America and the Caribbean, still maintain both the language and politics of working-class movements in ways that are seldom evidenced in the United States among previous generations of migrants (Bacon, 2004). ${ }^{9}$ The simple fact that May Ist-a forgotten holiday for most Americans-was chosen as the day for Migrant Rights marches across the country suggests a great deal about how the memory of class and race speak to each other in Latin American communities. 
While poets such as Gary Soto, Martín Espada, Juan Felipe Herrera, Diana García, and playwright Luis Valdez carry on the working-class tradition of early proletarian writers, I would like to conclude with a reading of Helena Viramontes' I 995 novel, Under the Feet of Jesus. As one of the more comprehensive contemporary narrative explorations of the subjective consciousness of workers through the lens of citizenship and race, Under the Feet of Jesus also considers the ways in which the "objective" conditions of labor have changed and that these changes produce with them new forms of working class consciousness. The novel tells the story of the young teenager, Estrella, and her family of migrant farm-workers in the central valleys of California. Like many of the proletarian novels, it's what Barbara Foley refers to as a "radical bildungsroman." Estrella gains not only in maturity and insight throughout the text, but political awareness ( I 993). ${ }^{\circ}$ Much of the early sections of the novel are dedicated to moments in which Estrella perceives her own identity in relationship to the class structure of the fields and towns through which she travels. In the first scene of Estrella working in the fields, we find her musing on the Sunmaid Raisins icon, a white woman in a red bonnet who "did not know" how hot, dirty, and dangerous the work is and whose bonnet would offer no protection in the harsh San Joaquin Valley sun (Viramontes, I 996). Likewise, Estrella's first lover, the college-bound Alejo who has fallen ill from pesticide poisoning, asks her if she intends to waste her life picking in the fields. Estrella's response, much like her reflection on the Sunmaid Raisin icon, asserts the value of her own labor in the face of classed assumptions of its value." What's wrong with picking peaches," she asks, a question that betrays a limited horizon of possibility but also the dignity of her work (ibid.).

Yet, unlike the revolutionary promise of Mike Gold's Jews without Money and Pietro di Donato's Christ in Concrete, the novel ends on an ambivalent note, with Estrella climbing to the top of a barn for a transcendent moment, gazing into stars that are her namesake. Ironically, however, it is the same barn that Perfecto will use the proceeds from demolishing to abandon her and her family. Indeed, the novel both asserts Estrella's dignity, value, and powerful subjective voice, while, far more often, trading in both surreal, disorienting imagery, liminal spaces, and ambiguous identities. 
Perfecto, her mother's lover and a kind of step-father, lives in a "travesty of laws," neither documented nor married to Petra, Estrella's mother (ibid.). Estrella, herself, is neither a teenager as she works full time and takes care of her ailing boyfriend - nor an adult. And the family is one of differing biological backgrounds, which encompass legal, national, and cultural relationships to both Mexico and the United States. Indeed, it is a novel of borders between citizen and non-citizen, family and non-family, childhood and adulthood-borders that are often obscure and uncertain from both a legal and subjective point of view.

Estrella's identity, often rooted in both her class and ethnic identity, also seems frequently on the verge splintering entirely. Coming across a baseball game after working in the fields, she is blinded by the lights and thinks for a moment that they were "the border patrol... and she tried to remember which side she was on" (ibid.). The baseball game further dissolves into "phantoms" as she wonders "where was home": the bat becomes a "blunt instrument against the skull"; the ball becomes a "peach" that one must run after in order to have money to eat. Estrella, who is a citizen, experiences her national identity as a moment not only of alienation, but of personal fragmentation - a game that is "America's national pastime" transforms into a border-on which side she stands, she doesn't know. The novel's title, Under the Feet of Jesus, refers to the papers that Estrella would need to show if she was ever stopped by La Migra, despite her birthright citizenship. While the novel certainly argues for Estrella's value and the dignity of her labor, her own sense of self is torn by her uneven relationship to family, age, and national status.

In a single dialectical image, she imagines herself both as drowning in the La Brea tar-pits she learns about from Alejo, and yet uses the image of tar to insist that it is the clinic at which she attempts to get Alejo treatment that owes her family. "Oil is made from our bones," Estrella thinks before she forcibly takes her family's last ten dollars back from a frightened nurse. She argues that the world literally runs on her labor like a car runs on gasoline, bringing her image of her own death into one of empowerment. Yet as the money is used to pay for the gas that will take Alejo to the hospital and away from her forever, it is an image that again returns 
back to a sense of ambiguity. If we return for a moment to Lukacs' subject-object of history, the idea of a unitary working class, or even a global working-class politics, may be as necessary as ever; but in the I990s when Under the Feet of Jesus appears, this solidarity seems absent. There is a brief moment when United Farm Worker activists show up in the field, pass Estrella a leaflet, and then fade back into the heat and dust of the field. Estrella's identity is fragmented much as the working-class movement is fragmented - riven by tightened borders, by the smashing of unions, by the collapse of international socialist and anti-colonial projects. Under the Feet of Jesus encodes this loss within Estrella's fragmented consciousness. It is not a novel of despair so much as defeat. Estrella does not lack class consciousness so much as that consciousness is personal, private, and able to be expressed only in individual acts of resistance. The "revolutionary subject" of History and Class Consciousness is perhaps latent, but as the "subject of history," it lacks a teleology of the future that can resolve its contradiction.

As Sonali Perera and Michelle Tokarczyk suggest in recent scholarly works on working- class literature, many of the ideas around working-class literature have changed as ideas and formations of class have changed in the last few decades, due to globalization as well as post-Cold War revisions of twentieth century working-class movements (Perera, 20I4; Tokarczyk, 20I I). As the class conscious nature of the Movement for Black Lives policy platform recently reinforced with its call for union rights, free education, and free health care, race and class in this country are profoundly intertwined and will likely continue to be. As such, the inheritance of both the ethnic proletarian tradition, as well as the longer tradition of writing about class and race in fiction, will undoubtedly continue. Whether they will be novels of white backlash, such as Philip Meyers's American Rust (201 I) - in which the enemies of the unemployed working class hero are sexually deviant, and racially-mixed homeless men-or they will be attempts to playfully reengage with the meaning of working-class oral traditions, such as Colson Whitehead's John Henry Days (200I) may be a function of future working class formations. Whether we can think of The Autobiography of Malcolm $X$ as the high point of working class literature that is now receding, or a mid-point in a much longer 
wave, has yet to be seen. The "laboring of American culture" in Michael Denning's phrase may be moving in many contradictory ways, but social movements suggest that a literature of class will continue to be needed. Already, new magazines such as Jacobin, Redwedge, and $N+I$ have foregrounded the class struggle and its connection to issues of race in new ways, similar to the Occupy movement and Black Lives Matter. Equally, as the globalized world dislocates an increasing number of migrants, these migrants bring with them organizing histories and political backgrounds that continue to produce new subjectivities and new life into working-class struggle. Hopefully, we can trust that novelists will emerge, who not only want to chronicle it but who lived it themselves.

\section{Notes}

I. Naison describes the frequent tensions between Garveyite nationalists and the Communist Party over ideological questions such as black capitalism, the CP's attacks on black landlords, and of course, the centrality of race or class as a prime analytic.

2. For further treatment of the zoot suit and the rebel subcultures that surrounded it, see Robin D.G. Kelley (I994) “The Riddle of the Zoot: Malcolm Little and Black Cultural Politics During World War II." Race Rebels: Culture, Politics, and the Black Working Class. New York, The Free Press; Eduardo Pagán (2003) Murder at the Sleepy Lagoon: Zoot Suits, Race, and Riot in Wartime L.A. Chapel Hill, University of North Carolina Press; Kathy Peiss (20I4) Zoot Suit: The Enigmatic Career of an Extreme Style. Philadelphia, University of Pennsylvania Press.

3. C.L.R. James famously refers to the black slaves of San Domingue as the world's "first proletariat" in the epilogue to his masterwork, The Black Jacobins, p. 392. For a more contemporary account of the origins of U.S. capitalism and finance through the institution of slavery, see Edward Baptiste (2014) The Half that has Never Been Told: Slavery and the Making of American Capitalism. New York, Basic Books.

4. See footnote 2; also see James Smethurst The New Red Negro: The Literary Left and American Poetry, I930-1946. Oxford, Oxford University Press, I999 and Robin D.G. Kelley, Race Rebels: Culture, 
Politics and the Black Working Class. New York: Simon and Schuster, 1996, and Hammer and Hoe: Alabma Communists: During the Great Depression. Chapel Hill, UNC Press, I990.

5. The full list of African American CPUSA members and "fellow travelers" that Wald lists in the review are here as follows: "Richard Wright...Margaret Walker, Lance Jeffers, Claude McKay, John Oliver Killens, Julian Mayfield, Alice Childress, Shirley Graham, Lloyd Brown, John Henrik Clarke, William Attaway, Frank Marshall Davis, Lorraine Hansberry, Douglas Turner Ward, Audre Lorde, W.E.B. Du Bois, and Harold Cruse were among those organizationally affiliated in individualized ways. A list of other African-American cultural workers who were, to varying degrees and at different points, fellow travelers, would probably include Ralph Ellison, Chester Himes, Sterling Brown, Langston Hughes, Paul Robeson, Theodore Ward, Countee Cullen, James Baldwin (as a teenager), Richard Durham, Alain Locke, Willard Motley, Rosa Guy, Sarah Wright, Jessie Fausett, Owen Dodson, Ossie Davis, Dorothy West, Marion Minus, Robert Hayden, Waring Cuney, and Lonne Elder III."

6. Denning, as do Foley and Wald, make very clear that despite the Soviet Union's formal call for socialist realism, few writers on the left followed the Party line with anything that could be described as orthodoxy or blind loyalty. The Cold War myth of the I930s "writer in uniform" has, I hope, been firmly laid to rest.

7. Gold, Jews without Money, p. 4I.

8. David Bacon makes the point that many Mexican and other Latin American immigrants bring with them the history of labor and social struggle that may help to re-energize the U.S. labor movement.

9. Barbara Foley coined the phrase "radical bildungsroman" to describe a key genre of I930s proletarian literature.

\section{References}

Adi, H. (2009). The Negro Question: The Communist International and Black Liberation in the Interwar Years. In: M. West, W. Martin, and F. Wilkins, eds., From Toussaint to Tupac: The Black International since the Age of Revolution. Chapel Hill, University of North Carolina Press, p. I 55. 
Bacon, D. (2004). The Children of NAFTA: Labor Wars on the U.S./ Mexico Border. Berkeley, University of California Press.

Berman, M. (1982). All That is Solid Melts Into Air: The Experience of Modernity. New York, Penguin Books.

Breitman, G. (I970). The Last Year of Malcolm X: The Evolution of a Revolutionary. New York, Pathfinder Press.

Daniels, R. (1998). Not Like Us: Immigrants and Minorities in America: I890-I924. Chicago, Ivan R. Dee Publishers.

Denning, M. (I998). The Cultural Front: The Laboring of American Culture. New York, Verso.

Denning, M. (2004). Culture in the Age of Three Worlds. London, Verso.

di Donato, P. (1993). Christ in Concrete. New York, Signet Classic.

Du Bois, W. E. B. (1998). Black Reconstruction in America: I860I 880 . New York, The Free Press.

Dunbar-Ortiz, R. (2002). One or Two Things I Know About Us: Rethinking the Image and Role of the 'Okies'. Monthly Review, 54 (3) (July-August). Available at: http://monthlyreview. org/2002/07/01/one-or-two-things-i-know-about-us/ [Accessed 30 Aug 2016]

Foley, B. (I993). Radical Representations: Politics and Form in U.S. Proletarian Fiction I929-I94I. Durham, Duke University Press.

Garrison, W. L. (2009). Preface. In: Narrative of the Life of Frederick Douglass. New York, Dover Publications, pp. 87-IOI.

Gold, M. (1972). Mike Gold: A Literary Anthology, Michael Folsom, ed., New York, International Publishers.

Gold, M. (2009). Jews without Money. Philadelphia, Public Affairs.

Haley, A. and Malcolm X. (20I 5). The Autobiography of Malcolm X as Told to Alex Haley. New York, Ballantine Books.

Hall, S. (1996). Race, Articulation, and Societies Structured in Dominance. In: H. A. Baker, Jr., M. Diawara and R. Lindborg, eds., Black British Cultural Studies Reader. Chicago, University of Chicago Press, pp. I6-6I. 
Jacobson, M. F. (I999). Whiteness of a Different Color: European Immigrants and the Alchemy of Race. Cambridge, Harvard University Press.

James, C. L. R. (1998). The Black Jacobins: Toussaint L'Ouverture and the San Domingo Revolution. New York, Vintage.

Jameson, F. (2009). Valences of the Dialectic. London, Verso.

Kaplan, A. (1988). The Social Construction of American Realism. Chicago, University of Chicago Press.

Kelley, R. (I990). Hammer and Hoe. Durham, Duke University Press.

Kelley, R. (1994). Race Rebels: Culture, Politics, and the Black Working Class. New York, Free Press.

Le Sueur, M. (I990). The Fetish of Being Outside. In: Harvest Song. Albuquerque, West End Press.

Lowe, L. (1996). Immigrant Acts: On Asian American Cultural Politics. Chapel Hill, Duke University Press.

Lukács, G. (1972). History and Class Consciousness: Studies in Marxist Dialects, trans. Rodney Livingston. Boston, MIT Press.

Marable, M. (20I I). Malcolm X: A Life of Reinvention. New York, Viking.

Maxwell, W. (I996). The Proletarian as New Negro: Mike Gold's Harlem Renaissance. In: B. Mullen and S. Linkon, eds., Radical Revisions: Rereading I93os Culture. Urbana-Champaign, University of Illinois Press, 9I-I20.

Mullen, B. V. (I999). Popular Fronts: Chicago and African-American Cultural Politics, I935-I946. Urbana-Champaign, University of Illinois Press.

Murphy, J. (I99I). The Proletarian Moment: The Controversy Over Leftism in Literature. Champaign-Urban, University of Illinois Press.

Naison, M. (1983). Communists in Harlem during the Depression. Urbana-Champaign, University of Illinois Press.

Ngai, M. M. (2004). Impossible Subjects: Illegal Aliens and the Making of Modern America. Princeton, Princeton University Press. 
Omi, M. and Winant, H. (I994). Racial Formation in the United States. New York, Routledge.

Perera, S. (20I4). No Country: Working Class Writing in an Age of Globalization. New York, Columbia University Press.

Rabinowitz, P. (I99I). Labor \& Desire: Woman's Revolutionary Fiction in Depression America. Chapel Hill, University of North Carolina Press.

Roediger, D. (1996). Wages of Whiteness: Race and the Making of the American Working Class. London, Verson.

Smethurst, J. (1999). The New Red Negro: The Literary Left and American Poetry, I930-1946. Oxford, Oxford University Press.

Shocket, E. (2000). 'Discovering Some New Race': Rebecca Harding Davis's 'Life in the Iron Mills' and the Literary Emergence of Working-Class Whiteness. PMLA, I I 5 (I), pp. 46-59.

Slotkin, R. (1998). Gunfighter Nation: The Myth of the Frontier in 2oth Century America. Norman, University of Oklahoma Press.

Steinbeck, J. (2006). The Grapes of Wrath. New York, Penguin Books.

Tokarczyk, M. M. (20II). Critical Approaches to Working-Class Literature. London, Routledge.

Viramontes, H. (I996). Under the Feet of Jesus. New York, Plume Press.

Wald, A. (2000). Review: African Americans, Culture and Communism: part I. Against the Current, [online] (May-June). Available at: https://www.solidarity-us.org/node/928 [Accessed 28 Sept 2016].

Wald, A. (20I4). Trinity of Passion: The Literary Left and the AntiFascist Crusade. Chapel Hill, University of North Carolina Press.

Wright, R. and Rosskam, E. (I94I). I2 Million Black Voices. New York, Basic Books.

Wright, R. (2007). Blueprint for Negro Writing. In: H. L. Gates, ed., The New Negro: Readings on Race, Representation, and African American Culture, I892-I938. Princeton, Princeton University Press, p. 269. 